\title{
On a subclass of analytic functions defined by Ruscheweyh operator
}

\section{AbDul Rahman SAlman Juma and Luminiţa-IOANA CotîRlă}

\section{ABSTRACT.}

By using the Ruscheweyh derivative, we have introduced a subclass of analytic functions with negative coefficients in the unit disc. Some properties of analytic function as necessary and sufficient coefficient condition for this class are provided. Distortion bounds, inclusion relation and various properties are also determined.

DEPARTMENT OF MATHEMATICS

AL-ANBAR UNIVERSITY

RAMADI-IRAQ

E-mail address: dr_juma@hotmail.com

DepartMENT OF MATHEMATics

TECHNICAL UNIVERSITY OF CLUJ NAPOCA

G. BARIŢIU 25, 400027 Cluj-NAPOCA, ROMANIA

E-mail address: Luminita. Cotirla@yahoo.com

E-mail address: Luminita.Cotirla@math.utcluj.ro 